\title{
SOSIALISASI LITERASI KEUANGAN SYARIAH PADA ANAK USIA DINI
}

\author{
Peni Haryanti ${ }^{1}$, Athi' Hidayati ${ }^{2}$, lesyah Rodliyah ${ }^{3}$, Choirun Nisful Laili ${ }^{4}$, \\ Sari Saraswati ${ }^{5}$ \\ 1 Universitas Hasyim Asy'ari Tebuireng Jombang \\ korespondensi email: peniha1190@gmail.com \\ ²Universitas Hasyim Asy'ari Tebuireng Jombang \\ email: browmas2@gmail.com \\ ${ }^{3}$ Universitas Hasyim Asy'ari Tebuireng Jombang \\ email: iesyah_rodliyah@yahoo.com \\ ${ }^{4}$ Universitas Hasyim Asy'ari Tebuireng Jombang \\ email: nisful.laili@gmail.com \\ ${ }^{5}$ Universitas Hasyim Asy'ari Tebuireng Jombang \\ email: sarisaraswati7@gmail.com
}

\begin{abstract}
Indonesia is a country with a majority Muslim population. In terms of quantity, it has big potential as a center for the development of Islamic finance. The lack of Islamic financial literacy has made the public do not understand the importance of Islamic financial institutions in terms of both the benefit of the world and the hereafter. The method of implementing this activity is carried out in four stages, namely (1) Planning, (2) Preparation, (3) Implementation, and (4) Evaluation Implementation. At the implementation stage, socialization of sharia financial literacy is carried out to students, teachers and guardians of students and mentoring. The results obtained from community service are the first percentage of understanding and knowledge of financial literacy which increased from $56,5 \%$ to $85 \%$ both students, teachers and guardians of students viewed from the results of the pretest and posttest that have been given. Secondly, during the mentoring the participants gave a positive response with a percentage of $86 \%$ and $100 \%$ interested in participating in the second phase of socialization in order to know the positive developments after obtaining mentoring as seen from the results of the questionnaire responses that had been given.
\end{abstract}

Keywords: islamic financial literacy; early childhood.

\begin{abstract}
ABSTRAK
Indonesia merupakan negara yang mayoritas penduduknya beragama Islam. Secara kuantitas berpotensi besar sebagai pusat pengembangan keuangan syariah. Minimnya literasi keuangan syariah menjadikan masyarakat belum memahami pentingnya lembaga keuangan syariah baik dari segi kemaslahatan dunia maupun akhirat. Metode pelaksanaan kegiatan ini dilakukan dalam empat tahap, yaitu (1) Perencanaan, (2) Persiapan, (3) Pelaksanaan, dan (4) Evaluasi. Pada tahap pelaksanaan dilakukan dengan melakukan sosialisasi tentang literasi keuangan syariah kepada siswa, guru, dan wali murid serta pendampingan. Hasil yang diperoleh dari pengabdian pada masyarakat adalah yang pertama persentase pemahaman dan
\end{abstract}


pengetahuan mengenai literasi keuangan mengalami peningkatan yang semula hanya sekitar 56,5 \% naik menjadi 85\% baik siswa, guru, dan wali murid dilihat dari hasil pretest dan postest yang sudah diberikan. Kedua, selama pendampingan para peserta memberikan respon positif dengan persentase $86 \%$ dan 100\% berminat mengikuti sosialisasi lanjutan jika diadakan kembali agar bisa mengetahui perkembangannya dilihat dari hasil angket respon yang sudah diberikan.

Kata Kunci: literasi keuangan syariah; anak usia dini.

\section{PENDAHULUAN}

Indonesia merupakan negara yang mayoritas penduduknya merupakan masyarakat yang beragama Islam. Secara kuantitas berpotensi besar sebagai pusat pengembangan keuangan syariah. Per tahun 2020 jumlah penduduk Indonesia mencapai 269,6 juta jiwa (Rama, 2015; Sujianto, Zaini, \& Rohmah, 2019), yang hampir separuhnya di pulau jawa. Hal ini menjadi kesenjangan dengan pulau-pulau yang lain, baik dari segi jumlah penduduk maupun dalam segi pembangunan maupun bidang lainnya. Namun hal ini tidaklah berbanding lurus dengan data, Indonesia masih tertinggal dari negara lain dalam hal pengembangan kuantitatif industri keuangan syariah, sebagaimana ditampilkan pada gambar 1 .

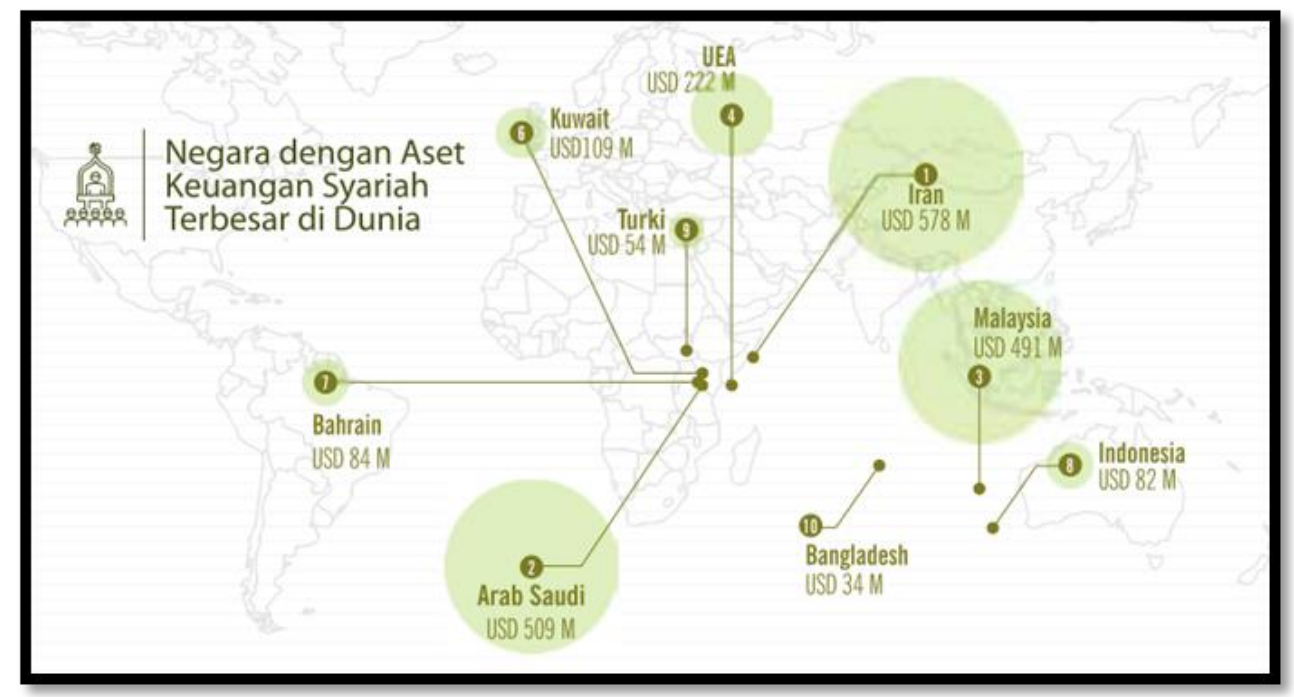

Gambar 1. Pandangan Komparatif Terhadap Perkembangan Keuangan Syariah

Salah satu penyebab rendahnya pengembangan kuantitatif industri keuangan syariah adalah minimnya kesadaran masyarakat tentang literasi keuangan khususnya literasi keuangan syariah. Mayoritas masyarakat Indonesia belum memahami bahwa pemahaman literasi keuangan syariah sangat diperlukan sebagai salah satu faktor pertumbuhan industri keuangan syariah di Indonesia (Putri \& Firmansyah, 2017; Rizal, Mustapita, \& Kartika Sari, 2020). Minimnya literasi keuangan syariah menjadikan masyarakat 
belum memahami pentingnya lembaga keuangan syariah baik dari segi kemasylahatan dunia maupun akhirat. Lembaga keuangan merupakan lembaga yang sesuai dengan prinsip syariah dengan tujuan untuk mencapai falah (Sadri et al., 2019; Hakim, 2020). Masyarakat masih menganggap lembaga keuangan syariah sama dengan lembaga keuangan konvensional. Hal ini dibuktikan dengan minimnya minat masyarakat untuk menggunakan jasa lembaga keuangan syariah.

Alat indikator perkembangan keuangan syariah milik Zawya-ICD memberi indikasi bahwa tingkat kesadaran masyarakat Indonesia hampir setara dengan Pakistan. Namun, secara signifikan lebih rendah dari pada Malaysia. Banyak cara dilakukan oleh pemerintah maupun pihak swasta dalam pengembangan keuangan syariah salah satu contoh adalah diadakan berbagai seminar yang berkaitan dengan keuangan syariah namun hal ini belum berbanding lurus dengan literasi keuangan syariah. Seminar belum mampu mengcover seluruh lapisan masyarakat, karena memang masyarakat Indonesia mayoritas adalah kalangan dengan tingkat pendidikan dasar. Sehingga seminar kurang efektif sebagai tolak ukurnya. Meskipun demikian ketika tolak ukur yang digunakan dalam pengukuran didasarkan pada jumlah seminar dan konferensi yang diadakan di masing-masing negara serta jumlah berita industri yang dipublikasikan, ditampilkan pada gambar 2 .

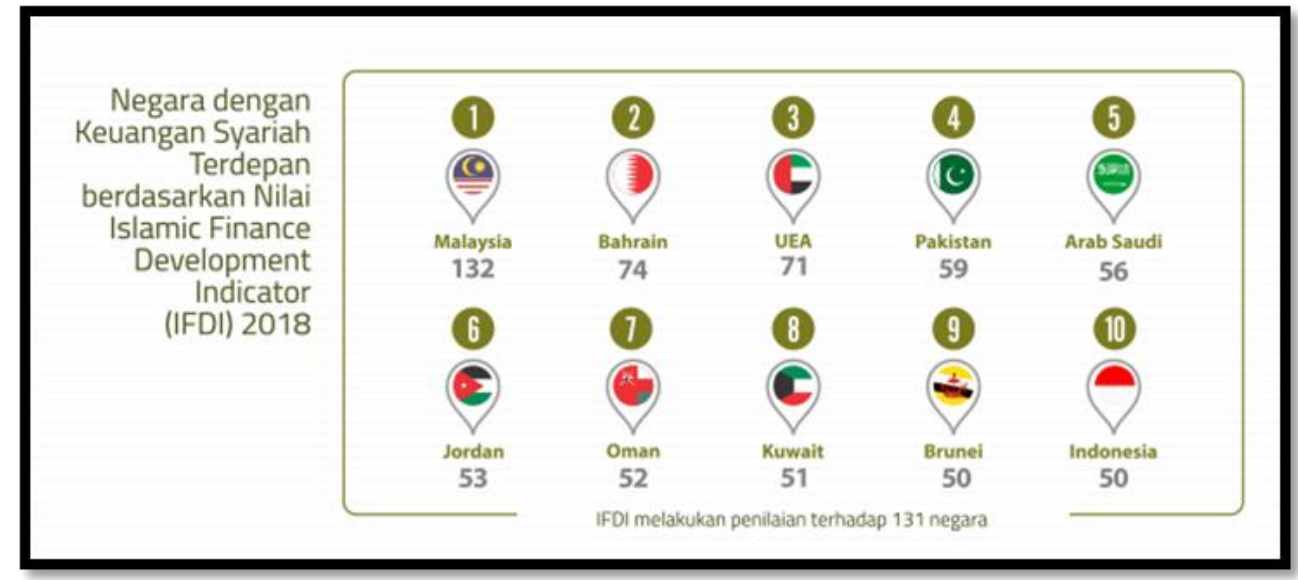

Gambar 2. Gambaran Negara dengan Keuangan Syariah Terdepan

Dengan data di atas, terlihat bahwa Indonesia masih jauh tertinggal. $\mathrm{Hal}$ ini yang menjadikan pemahaman literasi keuangan syariah sangat penting ditanamkan sejak dini sehingga masyarakat terbiasa mendengar dan paham tentang literasi keuangan syariah.

Hasil survey tingkat literasi dan inklusi keuangan syariah 2016, sebesar $8,11 \%$ dan indeks inklusi keuangan syariah 11,02\% (Adi, Sumarwan, \& Fahmi, 2018). Sebagaimana data-data tersebut dapat disimpulkan bahwa tingkat literasi keuangan syariah di Indonesia masih sangat rendah (Laily, 
2013). Untuk meningkatkan literasi keuangan syariah, maka diperlukan adanya edukasi keuangan yang baik. Menurut Akmal \& Saputra (2016) dalam Ekonomi Pembangunan Syariah menyatakan bahwa proses edukasi keuangan dianggap metode paling efektif untuk meningkatkan literasi keuangan terhadap masyarakat.

Sejalan dengan hal tersebut Kementerian Pendidikan dan Kebudayaan (Kemendikbud) telah mencanangkan program Gerakan Literasi Nasional (GLN) sejak tahun 2016. GLN merupakan respo Permendikbud No. 23 tahun 2015 tentang Penumbuhan Budi Pekerti. Pendidikan literasi keuangan sangat dibutuhkan untuk memberikan pendidikan kepada manusia agar sadar dan paham tentang bagaimana mengelola keuangan dengan bijak dan sesuai dengan kebutuhan (Hs \& Indriayu, 2017). Pendidikan literasi keuangan syariah pada anak tidaklah sekedar pengenalan uang, akan tetapi merupakan suatu konsep tentang pengenalan pengelolaan keuangan secara baik dan bijak (Kusuma dewi, Yusuf, and Si, M 2019). Yang dimaksud baik dan bijak disini yaitu anak diajarkan memilah-milah kebutuhannya. Bisa memilah antara kebutuhan maupun keinginan. Anak juga diajarkan untuk mengontrol keuangan dan diajarkan untuk gemar menabung (Rita \& Santoso, 2017).

Ada beberapa kalangan yang menganggap bahwa literasi keuangan sebaiknya diberikan ketika individu sudah remaja (Margaretha \& Pambudhi, 2015). Asumsi ini didasarkan karena anak-anak dianggap terlalu kecil untuk memahami keuangan. Di sisi lain, para ahli keuangan memberikan rekomendasi agar literasi keuangan diberikan semenjak dini, karena hal ini akan terakumulasi sampai dewasa. Perilaku yang muncul pada usia dini cenderung berkembang dan sulit diubah.

Taman Kanak-Kanak (TK) Kuncup Harapan merupakan salah satu lembaga pendidikan anak usia dini yang belum mengajarkan literasi keuangan kepada anak didiknya. Sehingga diperlukan adanya pengenalan literasi keuangan syariah baik kepada anak didik sekaligus guru sehingga guru mampu mengajarkan kembali kepada anak didik.

Taman Kanak-Kanak (TK) Kuncup Harapan berlokasi di Desa Bendungan Kecamatan Kudu Kabupaten Jombang, ditemukan persoalan sebagai berikut:

1. Anak-anak usia dini belum mengetahui tentang perbedaan antara kebutuhan dan keinginan.

2. Anak-anak usia dini belum bisa mengelola keuangan, hal ini dibuktikan ketika diberi uang saku dihabiskan semua tanpa disisakan untuk ditabung.

3. Minat menabung anak-anak cenderung kurang hal ini dibuktikan dengan minimnya anak yang mengisi tabungan (kaleng) saat berada di sekolah.

4. Belum adanya pengenalan literasi keuangan syariah kepada anak-anak usia dini di dalam kurikulum TK.

5. Guru sebagai pendidik dan pengajar belum memahami tentang literasi keuangan syariah. 


\section{METODE PELAKSANAAN}

Kegiatan pengabdian masyarakat dilakukan dalam bentuk sosialisasi dan pendampingan tentang literasi keuangan syariah yang akan dilaksanakan pada bulan Oktober sampai Desember 2019. Lokasi kegiatan ini dilaksanakan di balai desa Bendungan, Kecamatan Kudu Kabupaten Jombang. Metode pelaksanaan kegiatan menjelaskan tentang tahapan-tahapan atau langkahlangkah yang dalam menyelesaikan solusi yang ditawarkan untuk mengatasi permasalahan yang dihadapi oleh mitra. Berdasarkan permasalahan yang dihadapi oleh mitra maka solusi yang ditawarkan adalah memberikan sosialisasi tentang literasi keuangan syariah kepada siswa, guru dan wali murid. Seluruh kegiatan direncanakan selesai dalam waktu 3 bulan, adapun tahapan-tahapan kegiatan sebagaimana gambar 3.

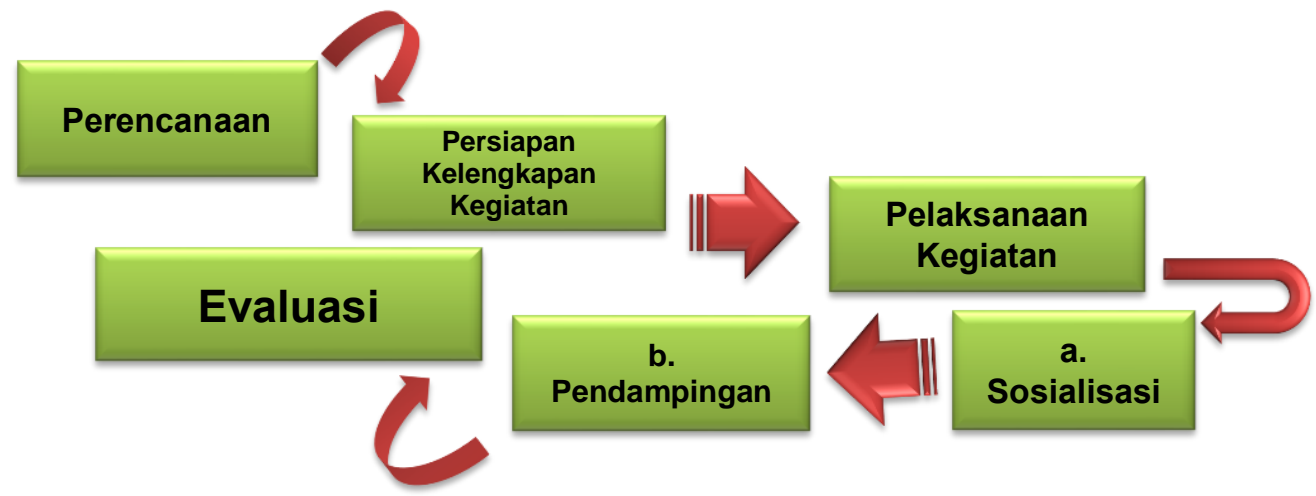

Gambar 3. Gambaran Tahapan Kegiatan Pengabdian Masyarakat

\section{HASIL DAN PEMBAHASAN}

Hasil Pengabdian Kepada Masyarakat dengan tema Sosialisasi Literasi Keuangan Syariah Pada Anak Usia Dini telah dilaksanakan dan sampai tahapan proses pendampingan untuk realisasi kaleng syariah. Kegiatan sosialisasi dilaksanakan 1 hari yaitu pada hari Kamis, 21 November 2019 bertempat di Balai Desa Bendungan Kecamatan Kudu Kabupaten Jombang yang mana lokasinya tepat berada di depat TK DW Kuncup Harapan. Sedangkan untuk pendampingan dilaksanakan selama 1 bulan yaitu pada bulan Desember 2019. Sasaran peserta kegiatan ini adalah siswa TK DW Kuncup Harapan yang berjumlah 53 siswa, namun ketika pelaksanaan terdapat guru dan juga wali siswa yang mana juga berminat mengikuti sosialisasi tersebut sehingga dapat membantu siswa untuk lebih memahami materi ketika sosialisasi berakhir, yaitu dengan mengulang-ulang materi ketika di rumah maupun di sekolah, pelaksanaan kegiatan sosialisasi ini juga dibantu oleh 5 mahasiswa. Hasil kegiatan setiap tahapan dijelaskan secara lengkap sebagai berikut: 


\section{Perencanaan}

Pada tahap ini dilakukan analisis situasi terhadap TK DW Kuncup Harapan Desa Bendungan, Kecamatan Kudu Jombang, kegiatan ini dilakukan dengan tujuan mengetahui gambaran secara langsung kegiatan belajar mengajar di kelas sekaligus mencari permasalahan-permasalahan yang mungkin terjadi di sekolah khususnya tentang pemahaman akan literasi keuangan.

Guru belum mengajarkan tentang literasi keuangan khususnya literasi keuangan syariah hal ini lah yang menjadikan tim pengabdi tergerak untuk melakukan pengabdian di TK DW Kuncup Harapan. Yang mana pendidikan anak usia dini merupakan pendidikan yang utama yang nantinya akan menjadi pondasi karakter untuk anak ke depannya. Sehingga masih belum ada kesadaran baik dari pihak sekolah maupun orang tua sebagai wali murid untuk mengajarkan anak tentang literasi keuangan yang sederhana.

Kegiatan ini bertujuan untuk mengambil langkah dalam memberikan solusi terbaik bagi mitra. Pemberian solusi ini bukan hanya asal tanpa dasar yang kuat. Namun, sudar didasarkan oleh pendapatpendapat para ahli hasil pengkajian/referensi yang terkait dengan tema PKM. Adapun solusi yang ditawarkan untuk mengatasi permasalahan mitra menjadi tema PKM ini yaitu "PKM Sosialisasi Literasi Keuangan Syariah Pada Anak Usia Dini di TK Dw Kuncup Harapan Ds. Bendungan". Materi literasi keuangan syariah dibagi menjadi 5 materi (Kusumadewi et al., 2019).Materi yang pertama pengertian traksaksi ekonomi dan berbagai macam jenis praktiknya, pengenalan sumber daya ekonomi (earning), pengenalan konsep belanja (spending), pengenalan konsep menyimpan (saving), pengenalan konsep berbagi (sharing), pengenalan konsep tentang berbagai macam praktik yang tidak sesuai dengan syariah dan kejahatan-kejahatan financial.

\section{Persiapan Kelengkapan Kegiatan}

Dalam persiapan kelengkapan kegiatan sosialisasi ada beberapa yang perlu disiapkan, di antaranya:

a. Mempersiapkan lokasi pelaksanaan sosialisasi, yaitu dengan mempersiapkan lokasi yang nyaman untuk anak usia dini. Balai desa menjadi pilihan lokasi sosialisasi selain tempatnya yang luas, sekaligus mampu menampung siswa, guru dan wali murid dan juga lokasinya bersebelahan dengan sekolah.

b. Mempersiapkan beberapa alat peraga yang mana alat peraga merupakan media yang paling mudah digunakan dan dimengerti oleh anak usia dini, selain itu mempersiapkan doorprise yang sesuai dengan tema sosialisasi yang sekaligus dapat digunakan sebagai media praktikum siswa. 
c. Mempersiapkan materi presentasi berupa power point baik berupa gambar, video dan video musik dan materi pendukung lainnya yang dirasa mudah diterima dan dimengerti oleh anak usia dini.

\section{Pelaksanaan Sosialisasi}

a. Sosialisasi

Pelaksanaan Sosialisasi di TK DW Kuncup Harapan selama 1 hari Tahapan ini merupakan tahapan sosialisasi yang dilaksanakan di TK DW Kuncup Harapan yang telah dilaksanakan tanggal 21 November 2019 dan pendampingan dilaksanakan selama 1 bulan yaitu bulan Desember. Siswa diberikan materi kemudian langsung diajak praktik secara langsung dengan memberikan kuis secara lisan. Selain itu siswa juga diajari dengan lagu edukasi anak yang merupakan lagu thematic yang sesuai dengan tema kurikulum pendidikan anak usia dini atau PAUD. Melalui lagu anak belajar kosa kata, belajar budi pekerti dari kekuatan kata-kata yang ada di dalam liriknya (Aisyah et al., 2014). Melalui lagu anak dipertajam perasaannya dengan irama dan birama. Music dipercaya mencerdaskan otak, mencerdaskan hati, emosional questient, menjadikan anak lebih ceria, bahagia dan optimis.

Dalam sosialisasi ini, peserta berkumpul di balai desa (lesehan). Sebelum sosialisasi di mulai peserta di berikan pertanyaan pretest lisan dan tulis yang bertujuan untuk mengetahui sejauh mana pemahaman siswa, guru dan wali murid terkait literasi keuangan syariah Pemateri berjumlah 5 orang, yang mana pemateri 1 dan 2 menjelaskan sekaligus pembagian door prisekemudian istirahat lima belas menit selanjutnya dilanjutkan dengan materi ke 3 dan 4 menjelaskan dan diajak untuk langsung praktik menyanyikan lagu tematik sekaligus pembagian door prise dan yang terakhir adalah siswa, guru dan wali murid diajak untuk membentuk kelompok kecil yang bertujuan untuk mempraktikkan apa yang telah dijelaskan sebelumnya sekaligus diberikan postest sebagaimana pretest yang dilakukan postest lisan dan tulis.

b. Pendampingan

Setelah dilaksanakan sosialisasi dilakukan pendampingan, yang mana salah satu materi yang ditekankan dalam sosialisasi adalah menabung dan berbagi. Pendampingan dilakukan untuk mengetahui apakah siswa khususnya mempraktikkan apa yang telah disampaikan dalam sosialisasi yaitu menabung dan sekalis hasil dari tabungan tersebut sebagian dibagikan kepada orang yang membutuhkan. Atau adanya program dimana setiap hari jumat diadakan infak yang menjadikan pentingnya pemahaman akan berbagi. 


\section{Evaluasi}

Tahap ini merupakan bagian proses manajemen dimana evaluasi bagian terpenting dari pelaksanaan kegiatan pengabdian masyarakat. Tahapan evaluasi diperuntukkan untuk mencari solusi atas masalah yang timbul selama proses pelaksanaan pengabdian masyarakat ini. Evaluasi dilaksanakan bersama tim internal untuk mengetahui sejauhmana keberhasilan dari kegiatan pengabdian masyarakat ini dilakukan. Hasil pretest dan posttest dari seluruh peserta pelatihan menunjukkan bahwa para peserta mengalami peningkatan sesudah mendapatkan pelatihan. Berikut Tabel persentase hasil peningkatan pemahaman materi oleh para peserta pelatihan.

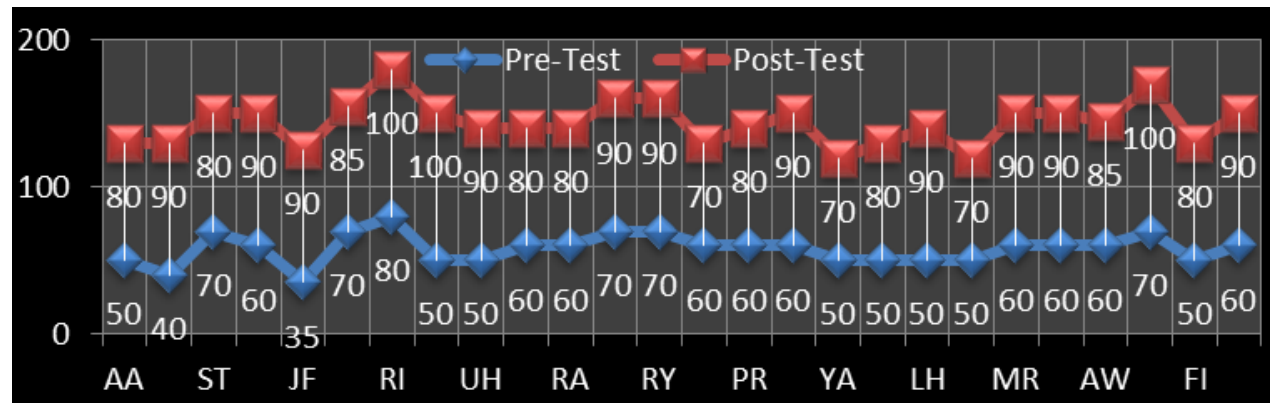

Gambar 4. Perbandingan Hasil Pretest dan Postest para peserta

Hasil respon positif para peserta terhadap pemateri pelatihan, pelaksanaan pelatihan, dan fasilitas pelatihan termasuk materi pelatihan berada pada kategori sangat baik dilihat dari hasil rata-rata semua peserta yaitu sebesar $86 \%$. Adapun minat para peserta untuk mengikuti kegiatan serupa jika diadakan lagi memperoleh respon yang sangat tinggi yaitu $100 \%$.

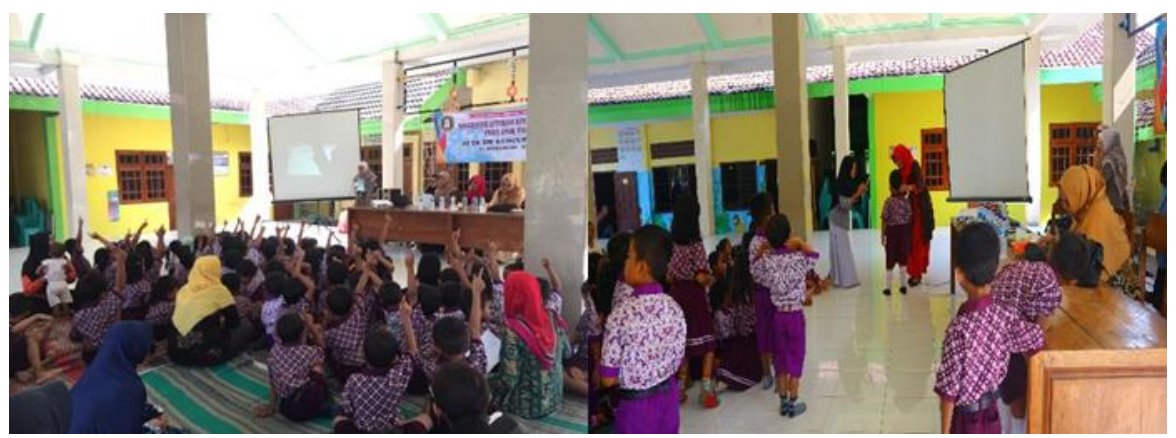

Gambar 5. Pelaksanaan Sosialisasi

\section{KESIMPULAN}

Berdasarkan hasil pelaksanaan kegiatan yang telah dilakukan, dapat disimpulkan bahwa 1) Para peserta yang hampir $80 \%$ belum pernah 
mendapatkan materi tersebut sebelumnya merasa sangat antusias mengikuti pelatihan, hal ini dibuktikan dengan para peserta yang aktif bertanya dan menjawab pada saat pelatihan berlangsung, 2) Penyampaian pengetahuan kepada peserta pelatihan dapat meningkatkan pengetahuan dan pemahaman mengenail literasi keuangan. Hal ini dibuktikan dengan persentase pemahaman dan pengetahuan mengenai literasi keuangan mengalami peningkatan yang semula hanya sekitar $56,5 \%$ naik menjadi $85 \%$ baik siswa, guru, dan wali murid dilihat dari hasil pretest dan postest yang sudah diberikan, 3) Selama pendampingan para peserta memberikan respon positif terhadap pemateri pelatihan, pelaksanaan pelatihan, dan fasilitas pelatihan dengan persentase rata-rata $86 \%$ dan $100 \%$ berminat mengikuti sosialisasi tahap kedua agar bisa mengetahui perkembangan positif setelah memperoleh pendampingan dilihat dari hasil angket respon yang sudah diberikan.

Kegiatan PKM tentang sosialisasi literasi keuangan syariah sangatlah penting untuk dilaksanakan terlebih lagi di era generasi milenial saat ini. Sehingga sebaiknya kegiatan PKM ini terus dikembangkan dan diterapkan dengan sasaran mulai anak usia dini, remaja, hingga dewasa guna mendidik manusia yang sadar dan paham tentang bagaimana mengelola keuangan dengan bijak dan sesuai dengan kebutuhan.

\section{DAFTAR RUJUKAN}

Adi, F., Sumarwan, U., \& Fahmi, I. (2018). Pengaruh Faktor Sikap, Norma Subjektif, Demografi, Sosioekonomi serta Literasi Keuangan Syariah dan Konvensional terhadap Minat Berwirausaha pada Mahasiswa. Jurnal Al-Muzara ah, 5(1), 1-20. https://doi.org/10.29244/jam.5.1.1-20

Aisyah, S., Amini, M., Chandrawati, T., \& Novita, D. (2014). Perkembangan dan Konsep Dasar Pengembangan Anak Usia Dini. In: Hakikat Anak Usia Dini. Universitas Terbuka.

Akmal, H., \& Saputra, Y. E. (2016). Analisis Tingkat Literasi Keuangan. Jebi (Jurnal Ekonomi Dan Bisnis Islam), 1(2), 235-244. https://doi.org/10.15548/jebi.v1i2.37

Hakim, M. A. R. (2020). Analisis Pengaruh Literasi Keuangan Syariah Terhadap Keputusan Membuka Rekening Bank Syariah (Studi Pada Mahasiswa Islam Kota Malang). Universitas Brawijaya.

Hs, S. R., \& Indriayu, M. (2017). Kajian Literasi Keuangan Pada Siswa Menengah Atas (Sma): Sebuah Pemikiran. Prosiding Seminar Pendidikan Ekonomi Dan Bisnis, 1-9. http://jurnal.fkip.uns.ac.id/index.php/snpe/article/view/10712/8389

Kusumadewi, R., Yusuf, H. A. A., \& Si, M, W. (2019). Literasi Keuangan Syariah Di Kalangan Pondok Pesantren.

Laily, N. (2013). Pengaruh Literasi Keuangan Terhadap Perilaku Mahasiswa Dalam Mengelola Keuangan. Journal of Accounting and Business Education, 1(4). https://doi.org/10.26675/jabe.v1i4.6042

Margaretha, F., \& Pambudhi, R. A. (2015). Tingkat Literasi Keuangan Pada 
Mahasiswa S-1. Jmk, 17(1), 76-85. https://doi.org/10.9744/jmk.17.1.76 Putri, S. A. M., \& Firmansyah, E. J. R. (2017). Optimalisasi Laku Pandai Berbasis Masjid Guna Literasi dan Inklusi Keuangan Syariah Berkelanjutan. JEBIS (Jurnal Ekonomi Dan Bisnis Islam), 3(2), 106121. https://doi.org/10.20473/jebis.v3i2.6464

Rama, A. (2015). Analisis Deskriptif Perkembangan Perbankan Syariah di Asia Tenggara. Journal of Tauhidinomics, 1(1), 1-25.

Rita, M. R., \& Santoso, B. (2017). Literasi Keuangan Dan Perencanaan Keuangan Pada Dana Pendidikan Anak. Jurnal Ekonomi, 20(2), 212227. https://doi.org/10.24912/je.v20i2.157

Rizal, M., Mustapita, A. F., \& Kartika Sari, A. F. (2019). Pelatihan Untuk Pengajuan Pembiayaan Mudharabah Perbankan Syariah Sebagai Peningkatan Kinerja UMKM. Jurnal Inovasi Hasil Pengabdian Masyarakat (JIPEMAS), 3(1), 15-22. https://doi.org/10.33474/jipemas.v3i1.2569

Sadri, M., Tinggi, S., Pendidikan, I., Maksum, A., Sei, J., Serangan, B., Bingai, K., Stabat, K., Langkat, K., \& Utara, S. (2019). Pemberdayaan Siswa Melalui Edukasi Keuangan Sejak Dini Sebagai Upaya Pembentukan Karakter Cerdas Mengelola Uang. Seminar Nasional Kewirausahaan (SNK 2019), 1(1), 290-295. https://doi.org/10.30596/snk.v1i1.3630 Pemberdayaan

Sujianto, A. E., Zaini, Z., \& Rohmah, L. (2019). Pendampingan Literasi Keuangan Syariah Penerbit Cahaya Abadi Tulungagung. E-Dimas: Jurnal Pengabdian Kepada Masyarakat, 10(1), 116. https://doi.org/10.26877/e-dimas.v10i1.3559 